\title{
INCIDENCE OF HEMATOLOGICAL MALIGNANCIES IN SICKLE CELL PATIENTS FROM AN INDIAN TERTIARY CARE TEACHING HOSPITAL
}

\author{
SIMA CHAUHAN ${ }^{1}$, SANTOSH KUMAR SWAIN ${ }^{2}$, MAHESH CHANDRA SAHU ${ }^{3 *}$
}

${ }^{1}$ Department of Pathology, Institute of Medical Sciences and Sum Hospital, Siksha 'O' Anusandhan University, Bhubaneswar - 751003 , Odisha, India. 'Department of Otorhinolaryngology, Institute of Medical Sciences and Sum Hospital, Siksha 'O' Anusandhan University, Bhubaneswar - 751 003, Odisha, India. ${ }^{3}$ Directorate of Medical Research, Directorate of Medical Research, Institute of Medical Sciences and Sum Hospital, Siksha ‘0’ Anusandhan University, Bhubaneswar - 751 003, Odisha, India. Email: mchsahu@gmail.com

Received: 16 November 2017, Revised and Accepted: 02 December 2017

ABSTRACT

Objective: Sickle cell disease (SCD) involves multiple systems and is manifested by variable degree of anemia, acute vaso-occlusive episodes, and chronic organ damage. Small case series have hinted at increased incidence of cancer among SCD patients, but no examination of population-based data in Odisha has been reported. Here, we have reported the association of hematological malignancies and SCD in our region.

Methods: In this prospective study, we have documented all the demographic and clinical data of sickle cell patients during the past 3 years from June 2013 to May 2016. Simultaneously, the bone marrow (BM) aspiration and biopsy were carried out for all patients. This study was approved from the Institutional Ethics Committee.

Results: A total number of 267 sickle cell patients were screened for malignancy by both BM aspiration and biopsy. Among them, 6 cases of malignancies were detected by both BM aspiration and biopsy method.

Conclusion: Our study shows a association between SCD and hematological malignancies which could be due to treatment with hydroxyurea or accumulation of multiple genetic abnormalities due to a high degree of proliferative activity of marrow cells.

Keywords: False-positive, Hematological malignancies, Sickle cell disease, True-positive.

(c) 2018 The Authors. Published by Innovare Academic Sciences Pvt Ltd. This is an open access article under the CC BY license (http://creativecommons. org/licenses/by/4. 0/) DOI: http://dx.doi.org/10.22159/ajpcr.2018.v11i3.22790

\section{INTRODUCTION}

The disorders resulting from sickle hemoglobin $(\mathrm{Hb}) \mathrm{S}$ are of enormous clinical importance as it is wildly distributed all over the world and also more prevalent. Sickle hemoglobinopathies are autosomal recessive hereditary diseases. The homozygous state (HbSS) is the most common form of sickle cell diseases (SCD). Interaction of $\mathrm{HbS}$ with thalassemia and certain variant haemoglobin like $\mathrm{HbC}$ and $\mathrm{HbD}$ potentiate sickling, while $\mathrm{HbF}$ has opposite effect and tend to diminish sickling [1]. HbS is responsible for a wide spectrum of disorders that vary with respect to degree of anemia, frequency of crisis, extent of organ injury, and duration of survival. The sickle mutation is the substitution of thymine for adenosine in the sixth codon of beta gene (GAG to GTG), thereby encoding valine instead of glutamic acid in the sixth position of the beta chain. This mutation is not oncogenic directly, sickle cell diseases (SCD), are mostly HbSS and $\mathrm{HbC}$ or thalassemia. SCD involves multiple system and manifested by variable degree of anemia, acute vasoocclusive episodes, and chronic organ damage [2]. SCD is associated with high degree of proliferation of bone marrow (BM) cells, chronic inflammation, and immune dysregulation. All together can predispose to malignancy. The association of SCD with malignancies has started appearing in some journals and the possible cause pointed out was the use of hydroxyurea [3-7].

The development of malignancy in persons with SCD has been documented by numerous individual cases [8-15] and several small series [13-15] over the past 50 years. These scattered reports document that malignancy occurs in both children and adults with SCD but do not provide complete data on the types of cancer or attempt to define the incidence of cancer in this patient population $[5,6]$. On the basis of a single institution study, the cancer incidence among patients with SCD has been reported to be 1.74 cases per 1,000 patient years [16].
$\mathrm{HbS}$ is so-called, because of the sickle shape, it imparts to deoxygenated red cells, is responsible for a wide spectrum of disorders that vary with respect to degree of anemia, frequency of crisis, extent of organ injury, and duration of survival. Some of the sickling syndrome significant pathologic potential. They should be confuged with clinically aggressive disorder on the basis of laboratory evaluation. Precision of diagnosis is essential both for proper clinical management and for meaningful genetic counseling. The highest prevalence of $\mathrm{HbS}$ is in tropical Africa and among blacks. It occurs in lower frequency in Mediterranean basin, Saudi Arabia, and part of India. DNA polymorphism study showed that $\beta^{\text {s }}$ gene arose from three independent mutations in tropical Africa. The most common $\beta^{\text {s }}$ chromosome is found in central waste Africa. A second haploid type is prevalent in African waist cost, Senegal, and third haploid is seen in the central African Republic. These are seen in Black American and Jamaican [9-11]. The HbS gene in the eastern province of South Arabia and central India is associated with a different DNA structure, i..e., not encountred in Africa and probably represent a fourth independent occurrence of the sickle cell mutation. To date, however, there has been no comprehensive compilation of malignancy in patients with SCD using data from multiple institutions with a large patientyear denominator. This scarcity of data is currently germane because of ongoing concerns regarding the carcinogenic risks of hydroxyurea. Additional data about malignancy in patients with SCD would help future cases to be placed into proper perspective [12]. The International Association of Sickle Cell Nurses and Physician Assistants (IASCNAPA) is a worldwide organization consisting of healthcare professionals who work directly with patients with SCD. IASCNAPA sent a survey to its members requesting information about cases of malignancy in patients with SCD followed at their institutions. The results of this survey are summarized in this report $[13,14]$. 
Due to the prevalence and worldwide distribution, the disorder resulting from sickle HbS is of clinical importance. Sickle cell anemia (HbSS) alone is the most common heritable hematologic disease affecting human. The $\mathrm{Hb}$ synthesis has got a genetic bases, and each major hemoglobinopathy occurs in both a heterozygous and a homozygous form. In heterozygous state, red cell contains both normal adult $\mathrm{Hb}$ and variant $\mathrm{Hb}$. They rarely have phenotypic expression of clinical significance, and they are said to have the trait for that abnormalities. In the homozygous state, SCD $\mathrm{HbA}$ is totally lacking and clinical manifestations are of variable severity and individual so affected have anemia. In addition, disease may result from the combination of these variant $\mathrm{Hb}$ or from this variant $\mathrm{Hb}$ and an interacting thalassemia gene. These doubly heterozygous statuses are designated by both aberrant gene products such as HbSC disease or $\mathrm{Hbs} / \beta$ thalassemia. The term SCD is used in a generic sense to refer to all of the stickling syndrome [1,2].

In sickle mutation, thymine is substituted for adenine at $6^{\text {th }}$ position of the $\beta$ gene (GAG $\rightarrow$ GTG), thereby coding for valine instead of glutamic acid. This minor change in structure is responsible for profound changes in molecular stability and solubility. The study shows that distortion of cells containing $\mathrm{Hb}$ is the result of $\mathrm{Hb}$ polymerization. Deoxy HbS polymers in the cell exist in a spectrum of forms from scattered individual fibers to highly ordered fibroid aggregate that essentially filled the cell and distorted it into the classic sickle cell or other elongated form [1-5]. Here, we have reported the association of hematological malignancies and SCD in our region.

\section{METHODS}

In this prospective 3 years study, we have evaluated the presence of malignancy in sickle cell disorder patients attending to the outpatient department of the Department of Clinical Hematology, Pediatrics, and Medicine. The demographic data of all the patients were documented, then detailed clinical history, complete hemogram, peripheral blood smear study, ultrasonography (USG) abdomen, capillary zone electrophoresis, and BM examination were carried out.

In clinical history, we have noted down the history of SCD in the family with pedigree analysis, history of acute crisis/sickle cell crisis, history of blood transfusion, history of hospitalization, and history of drug therapy. For complete hemogram, $2 \mathrm{ml}$ of ethylenediaminetetraacetic acid (EDTA) blood was collected in 2 vials. From vial one, we performed $\mathrm{Hb} \%$, total lymphocyte count, total protein concentration, mean corpuscular volume, mean corpuscular $\mathrm{Hb}(\mathrm{MCH}), \mathrm{MCH}$ concentration, hematocrit, red cell distribution width-coeficient variation and standard deviation, reticulocyte count, sickling test, and differential count. For sickling test, $50 \mu \mathrm{L}$ of blood was taken over a glass slide, then a coverslip was put over that so that no air bubble under the coverslip adjusted to get rid of all the air bubbles underneath the coverslip. Then, all sides of the coverslip were sealed with the help of molten wax. For quick results (30 min- 2 h) of sickling, we added 2 drops of freshly prepared $2 \%$ sodium metabisulfite to 2 drops of EDTA blood. The samples were mixed and processed like the earlier wax sealing method. The slides were incubated at $37^{\circ} \mathrm{C}$ for $12-24 \mathrm{~h}$, then the slides were examined under microscope. From $2^{\text {nd }}$ vial, we performed $\mathrm{Hb}$ capillary zone electrophoresis using Sebia minicap.

\section{Hb capillary zone electrophoresis}

During the procedure of $\mathrm{Hb}$ capillary zone electrophoresis, $2 \mathrm{ml}$ of blood sample was collected in EDTA vial and centrifuged with 4000 revolutions per minute for $5 \mathrm{~min}$. The supernatants were discarded and red blood cell mass was run in the minicap electrophoresis analyzer. During this process, sodium hypochloride was used for washing purpose. The analysis takes 10-15 min and the results were generated in the form of graph with reference to control graph. As soon as the analysis is complete, the relevant percentages and/or the concentrations of the different fractions are calculated automatically. To view the curves as tiled images and edit the curve, the curve is selected in the format command from the "edit curves" menu. USG abdomen, imaging of skull, long bones, and pelvis of all patients were carried out in the radiology department of our institution.

BM examination, both aspiration and biopsy were done. Under the procedure, the patients were lied down in Lt/Rt lateral recumbent posture. The BM aspiration is usually done first. The $2 \%$ xylocaine and local anesthesia was infiltrated at the site of left/right posterior superior iliac crest. Then, a small incision was made, then a Jamshedii's hollow needle was inserted through the bone and into the BM as a rotatory movement till a sense of giving way is felt. With the help of a syringe, sample of the liquid portion of the BM was withdrawn. The sample was spread over 5/6 number of glass slides, then smears were made. The needle was partially withdrawn and the direction of needle was changed. Bone marrow biopsy was done. After air dry, the smears were fixed with $70 \%$ alcohol for $15 \mathrm{~min}$. Then, the slides were stained with May Grunwald Giemsa. One to two sides were left for special stain like myeloperoxydase/Sudan black B. After that slides were examined under the microscope for a scanner, high power, and oil immersion view. The biopsy specimens were collected in formalin vial and then kept for decalcification and fixation. Then, processed in automated tissue processor (Lyca), cutting done in microtome to make thin section of 3-4 $\mu$ thickness, mounted over slides $\mathrm{H}$ and $\mathrm{E}$ stained, and examined under microscope.

\section{RESULTS}

With 3 years study period, 267 suspected sickle patients were screened for malignancy. Among the 267 patients, 103 were male and rest 164 were female, i.e., females were predominant to males (Table 1). Six different genotypes SCDs were noted during the study period (Table 1). Both peripheral blood smearing and $\mathrm{Hb}$ electrophoresis methods were used for the detection of SCDs. It was revealed that 124 were positive in both cases, i.e., true-positive $(\mathrm{TP})=124$. Whereas, 138 were negative at both these cases truenegative $(\mathrm{TN})=128$. In consideration to gold standard, i.e., $\mathrm{Hb}$

Table 1: Sickle cell syndrome along with age and sex distributation of suspected cases from the clinicians

\begin{tabular}{|c|c|c|c|c|}
\hline Genotype and sex & Gender & Number of patients & Age mean & Association with malignancy \\
\hline \multirow[t]{2}{*}{ SCD } & Male & 60 & 14.2 year & 1-AML-M2 \\
\hline & Female & 69 & 18.7 year & 1-AML-M3 \\
\hline \multirow[t]{2}{*}{ Sickle cell anemia with alpha thalassemia } & Male & 1 & 9 months & Nil \\
\hline & Female & 2 & 1 year & Nil \\
\hline \multirow[t]{2}{*}{ Sickle cell trait } & Male & 30 & 24.6 year & 1-ALL \\
\hline & Female & 84 & 23.2 year & 1-ALL, 2-M.M. \\
\hline Sickle cell-HbC disease & Male & 2 & 27.5 year & Nil \\
\hline \multirow[t]{2}{*}{ Sickle cell beta thalassemia+ } & Male & 3 & 26 year & Nil \\
\hline & Female & 3 & 27.5 year & Nil \\
\hline \multirow[t]{2}{*}{ Sickle cell beta thalassemia 0} & Male & 7 & 14.8 year & Nil \\
\hline & Female & 5 & 15.2 year & Nil \\
\hline
\end{tabular}

SCD: Sickle cell disease, HbC: Hemoglobin C, AML: Acute myeloid leukemia, ALL: Acute lymphoblastic leukemia 
electrophoresis false-positive and false-negative were 5 and 128 , respectively (Table 2). To consider about malignancy, two protocols were adopted, i.e. peripheral blood smearing and BM aspiration. The TP and TN were 3 and 257, respectively (Table 3). Out of total

Table 2: Diagnosis of sickle cell with respect to blood peripheral smear and $\mathrm{Hb}$ electorphoresis

\begin{tabular}{llll}
\hline $\begin{array}{l}\text { Hemogram and } \\
\text { blood ps }\end{array}$ & \multicolumn{2}{l}{ Hb electrophoresis } & \multirow{2}{*}{ Total } \\
\cline { 2 - 3 } & $\begin{array}{l}\text { Sickle } \\
\text { positive }\end{array}$ & $\begin{array}{l}\text { Sickle } \\
\text { negative }\end{array}$ \\
\hline Sickle positive & $\mathrm{TP}=124$ & $\mathrm{FP}=5$ & $(\mathrm{TP}+\mathrm{FP})=129$ \\
Sickle negative & $\mathrm{FN}=128$ & $\mathrm{TN}=10$ & $(\mathrm{FN}+\mathrm{TN})=138$ \\
Total & $(\mathrm{TP}+\mathrm{FN})=252$ & $(\mathrm{FP}+\mathrm{TN})=15$ & $\mathrm{~N}=267$ \\
\hline
\end{tabular}

Hb: Hemoglobin, TP: True-positive, FN: False-negative, FP: False-positive, TN: True-negative

Table 3: Diagnosis hematopoietic malignancy according to blood peripheral smear and BM aspiration

\begin{tabular}{|c|c|c|c|}
\hline \multirow{2}{*}{$\begin{array}{l}\text { Hemogram and } \\
\text { blood ps }\end{array}$} & \multicolumn{2}{|c|}{ BM aspiration } & \multirow[t]{2}{*}{ Total } \\
\hline & $\begin{array}{l}\text { Blast } \\
\text { positive }\end{array}$ & $\begin{array}{l}\text { Blast } \\
\text { negative }\end{array}$ & \\
\hline Blast positive & $\mathrm{TP}=3$ & $\mathrm{FP}=1$ & $(\mathrm{TP}+\mathrm{FP})=4$ \\
\hline Blast negative & $\mathrm{FN}=6$ & $\mathrm{TN}=257$ & $(\mathrm{FN}+\mathrm{TN})=263$ \\
\hline Total & $(\mathrm{TP}+\mathrm{FN})$ & $(\mathrm{FP}+\mathrm{TN})$ & $\mathrm{N}=267$ \\
\hline
\end{tabular}

Table hemogram and blood ps. BM: Bone marrow, TP: True-positive, FN: Falsenegative, FP: False-positive, TN: True-negative malignancies associated with SCD, 4 cases were of acute leukemias and 2 cases of multiple myeloma. 4 cases of acute leukemia comprised of 1 case of acute myeloid leukemia (AML)-M3, one case of AML-M2, and 2 cases of acute lymphoblastic leukemia (ALL) (Table 4).

Only 2 cases have a definite history of therapy with hydroxyurea. Other cases were sickle cell traits and double heterozygous and had no history of taking hydroxyurea, infect first they presented as hematological malignancies and retrospectively were found to have sickle cell hemoglobinopathies in capillary zone electrophoresis. Complete hemogram revealed the leukemia status of the patient. In 2 cases of acute promyelocytic leukemia ([APML], AML), the patient presented with peripheral blood shows blasts. In APML (Fig. 1), capillary zone electrophoresis revealed $53.2 \% \mathrm{HbS}$ (Fig. 2), with multiple units of blood transfusion. In AML, patient presented with acute respiratory distress syndrome and pleural effusion. Peripheral smear revealed blasts and irreversible sickle cell.

In one case of multiple myeloma, 65 years of lady presented with painful crisis episodes and peripheral smear revealed rouleaux and irreversible sickle cells, which (crisis) is unusual in this age. BM evaluation revealed multiple myeloma and the other case presented similarly but without SC crisis. In all these cases, patients concurrently presented hematological malignancies (4 cases being leukemia and 2 cases of multiple myeloma) and sickle cell hemoglobinopathies. In 4 cases, there was no history of hydroxyurea therapy. In other 2 cases ALL and AML, the patients were known cases of SCDs and were treated with hydroxyurea. One case of multiple myeloma and sickling (wax sealing) preparation of peripheral blood showed sickle cells after 12 $\mathrm{h}$ of incubation (Fig. 3), and the corresponding BM aspiration showed plasmablasts (Fig. 4).

Table 4: Clinical data of patients of association of SCD with hematological malignancies

\begin{tabular}{|c|c|c|c|c|c|c|c|c|}
\hline Age & Sex & $\mathrm{Cl} / \mathrm{F}$ & $\begin{array}{l}\text { Prior T/T history } \\
\text { (hydroxyurea) }\end{array}$ & PS findings & $\begin{array}{l}\text { Hb } \\
\text { electrophoresis }\end{array}$ & $\begin{array}{l}\text { Protein } \\
\text { electrophoresis }\end{array}$ & BM & $\begin{array}{l}\text { Final } \\
\text { diagnosis }\end{array}$ \\
\hline 2.6 & $\mathrm{~F}$ & $\begin{array}{l}\text { Fever, pallor, } \\
\text { hepatosplenomegaly }\end{array}$ & $\begin{array}{l}\text { +Known case } \\
\text { of sickle cell } \\
\text { hemoglobinopathy } \\
\text { on hydroxyurea }\end{array}$ & $\begin{array}{l}\mathrm{Hb}=6.2 \\
\mathrm{~g} \% \mathrm{WBC}=5000 / \\
\text { cu.mm } \\
\mathrm{PLT}=37.000 / \\
\text { cu.mm blast }=45 \%\end{array}$ & $\begin{array}{l}\mathrm{HbS}=34 \% \text { imp- } \\
\text { sickle cell trait }\end{array}$ & NA & Blast=91\%, mpo- & $\begin{array}{l}\text { ALL with } \\
\text { sickle cell } \\
\text { trait }\end{array}$ \\
\hline 25 & $\mathrm{~F}$ & Weakness, fever & - & $\begin{array}{l}\mathrm{Hb}=8.2 \mathrm{~g} \% \\
\mathrm{WBC}=680 / \text { cu.mm } \\
\mathrm{PLT}=53.000 / \\
\text { cu.mm occasional } \\
\text { blast }\end{array}$ & $\begin{array}{l}\mathrm{HbS}=53.2 \% \text {, after } \\
\text { multiple blood } \\
\text { transfusions. } \\
\text { Imp=SCD }\end{array}$ & NA & $\begin{array}{l}\text { Blast+abnormal } \\
\text { promyelocytes }=61 \% \text {, } \\
\text { mpo+ }\end{array}$ & $\begin{array}{l}\text { AML-M3 } \\
\text { with SCD }\end{array}$ \\
\hline 50 & $\mathrm{~F}$ & $\begin{array}{l}\text { Fever, weakness, low } \\
\text { backache }\end{array}$ & - & $\begin{array}{l}\mathrm{Hb}=7.9 \mathrm{~g} \% \\
\mathrm{WBC}=1280 / \\
\text { cu.mm } \\
\text { PLT }=60.000 / \\
\text { cu.mm, rouleaux+ }\end{array}$ & $\mathrm{HbS}=38 \%$ & $\begin{array}{l}\text { Monoclonal } \\
\text { protein }=5.76 \\
\mathrm{~g} / \mathrm{dl}\end{array}$ & Plasma cells $=18 \%$ & $\begin{array}{l}\text { Multiple } \\
\text { myeloma } \\
\text { with sickle } \\
\text { cell trait }\end{array}$ \\
\hline 19 & M & $\begin{array}{l}\text { Fever, weakness, } \\
\text { ARDS }\end{array}$ & $\begin{array}{l}+ \text { (Known case } \\
\text { of sickle cell } \\
\text { hemoglobinopathy } \\
\text { on hydroxyurea }\end{array}$ & $\begin{array}{l}\mathrm{Hb}=7 \mathrm{~g} \% \\
\mathrm{WBC}=45.000 / \\
\text { cu.mm } \\
\mathrm{PLT}=30.000 / \\
\text { cu.mm blast }=30 \% \text {, } \\
\text { sickle cells++ }\end{array}$ & $\mathrm{HbS}=78 \%$ & NA & Blast $=80 \%, \mathrm{mpo}+$ & $\begin{array}{l}\text { AML-M2 } \\
\text { with SCD }\end{array}$ \\
\hline 20 & M & Fever & - & $\begin{array}{l}\mathrm{Hb}=5 \mathrm{~g} \% \\
\mathrm{WBC}=16.000 / \\
\text { cu.mm } \\
\text { Plt }=40,000 / \text { cu.mm } \\
\text { blast }=40 \%\end{array}$ & $\mathrm{HbS}=39 \%$ & NA & Blast $=72 \%$, mpo- & $\begin{array}{l}\text { ALL with } \\
\text { sickle cell } \\
\text { trait }\end{array}$ \\
\hline 54 & M & Low backache & - & $\begin{array}{l}\mathrm{Hb}=6.2 \mathrm{~g} \% \\
\mathrm{WBC}=8.000 / \\
\text { cu.mm, } \\
\text { PLT=40,000/ } \\
\text { cu.mm }\end{array}$ & Hbs $=29 \%$ & $\begin{array}{l}\text { Monoclonal } \\
\text { protein=4.2 g/dl }\end{array}$ & Plasma cells=39\% & $\begin{array}{l}\text { Multiple } \\
\text { myeloma } \\
\text { with sickle } \\
\text { cell trait }\end{array}$ \\
\hline
\end{tabular}

SCD: Sickle cell disease, Hb: Hemoglobin, BM: Bone marrow, ARDS: Acute respiratory distress syndrome, WBC: White blood cell, AML: Acute myeloid leukemia, ALL: Acute lymphoblastic leukemia, PLT: Platelet 


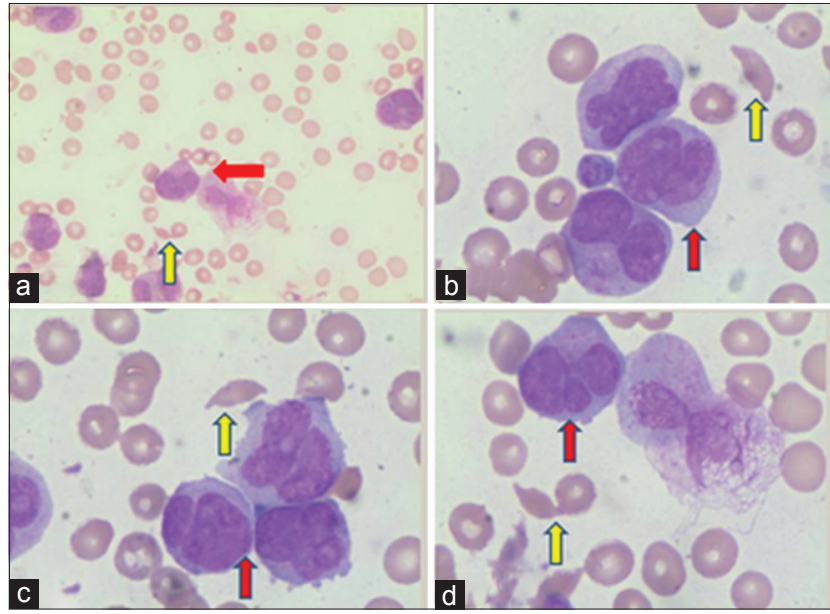

Fig. 1: (a-d) - Peripheral smear showing blast sickle cells. 1 A-H and E-40×10. 1 (b-d)-H and E-100×10. Red arrow - blast, yellow arrow - sickle cells

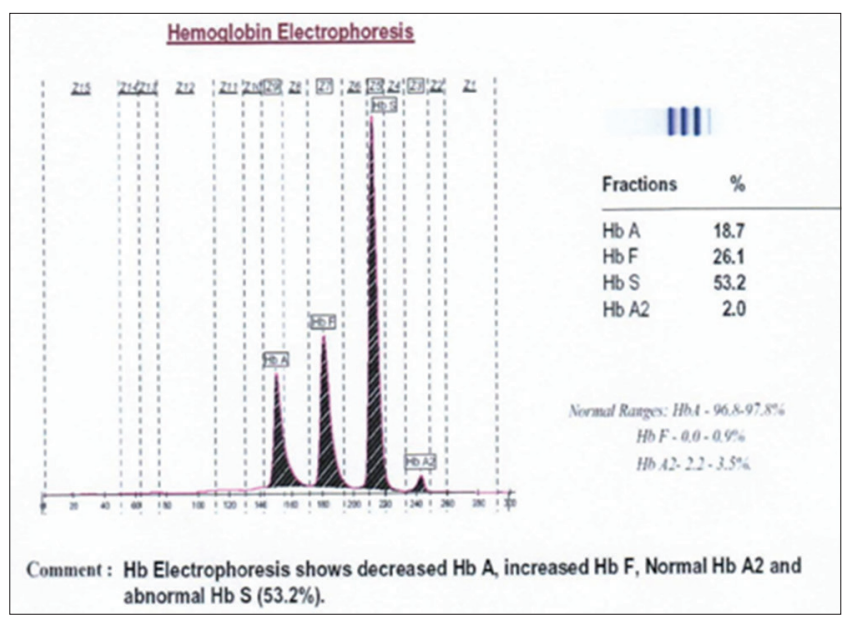

Fig. 2: Capillary zone electrophoresis, showing Hb S-53.2\%

\section{DISCUSSION}

In 1986, Stricker et al. [13] reported four adult cases of cancer in SCD and summarized 13 previously reported cases of leukemia and lymphoma. They concluded that SCD likely not only provided no increased risk of cancer developing but also conferred no protection. Solid tumors have also been previously reported in patients with SCD $[10,12]$ including the development of renal cell carcinoma even in persons with sickle cell trait $[11,15]$. Among more than 267 patients enrolled in the cooperative study of SCD (CSSCD), two patients had previous cancer at entry, three patients had a malignancy develop during the original 3-year study period, and one additional patient had cancer develop during the past year period. Our survey documented a wide variety of cancers in children and adults with SCD, including leukemia, lymphoma, and solid tumors. Most of our pediatric cases had leukemia, lymphoma, or Wilms' tumor, which are among the most common types of cancer (along with brain tumors and neuroblastoma) in unaffected children $[17,18]$. Altogether, our 6 cases of cancer represent by far the largest number of patients with SCD and malignancy reported to date. The true incidence of cancer in SCD remains unknown, even with the availability of prospectively collected CSSCD data. Before conducting this survey, we contacted the Duke Comprehensive Cancer Database, California Cancer Registry, North Carolina Central Cancer Registry, National Cancer Data Base, North American Association of Central Cancer Registries, and Surveillance, Epidemiology, and End Results. In each of these established databases, comorbid variables including SCD are not collected. Dawkins et al. [16] calculated the incidence of cancer

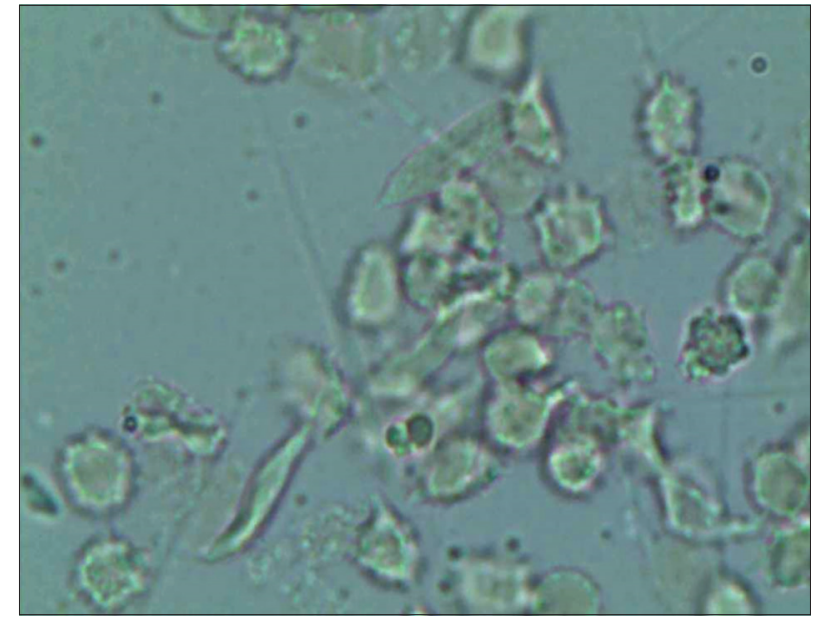

Fig. 3: Sickling preparation (wax sealing), showing sickling change. $100 \times 10$

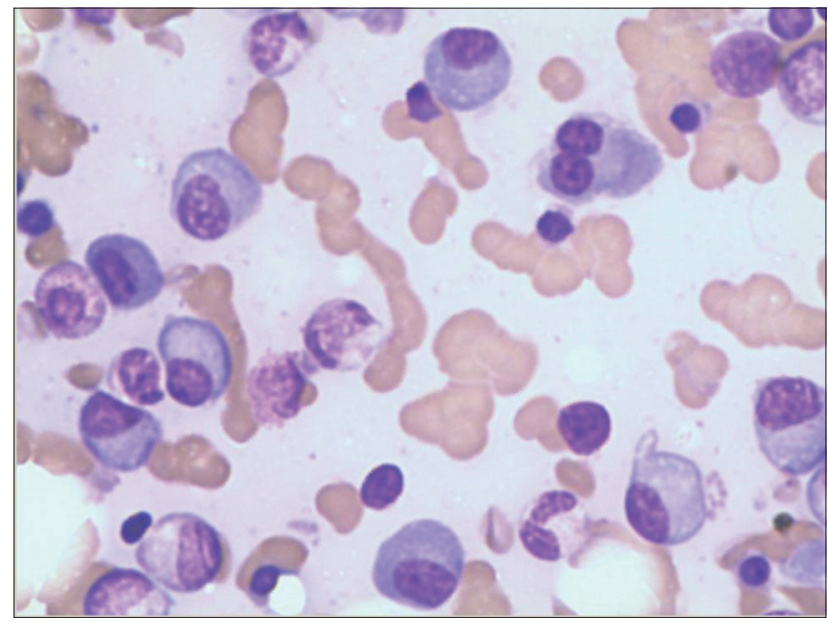

Fig. 4: Bone marrow aspiration smear showing plasma blasts and abnormal plasma cells. $100 \times 10$

in SCD at Howard University as 1.74 per 1.000 patient-years, roughly comparable to the incidence ( 3.82 cases per 1.000 patient-years) for the general African-American population [19].

Previous publications regarding SCD and hematological malignancies have been limited to case reports and few published studies [20]. Hydroxyurea is an important therapeutic agent for those with SCD. It's use, however, has been limited over concerns regarding the development of hematological malignancies including leukemia [21]. However, it has been reported that mortality was reduced in sickle cell patients exposed to hydroxyurea. Moreover, although there have been case reports of leukemia developing in patients on hydroxyurea, an actual link between this drug and the development of malignancy has yet to be determined. Advances in medical therapy, screening, and patient education will likely prolong the lifespan of many patients with SCD. The average life expectancy in patients with SCD has improved significantly. It is possible that the longer patient's live with SCD, the more likely they are to develop malignancies, including hematological malignancies [22]. Oral cancer accounts for a significantly higher percentage of all cancer cases. Survival rates of oral cancers are relatively low in comparison to other major cancers, although incidence rates are as low as 3\% [23]. Manifestation of oral cancer should be differentiated from the oral manifestations of hematological malignancies and SCD. The technical abilities to detect novel, resistant mechanisms and to overcome the microbial resistance have to be improved. To improve the mortality and morbidity of the patients and restrict the development 
of resistant bacteria in sickle cell patients. Antibiotic policies agreed among clinicians, microbiologists, and pharmacologists will guide good prescribing, provide maximum coverage for treating infections, and ensure antibiotic cycling [24].

\section{CONCLUSION}

There is a definite association between SCD and hematological malignancies. The association could be due to following two regions. The exact association is yet to be ascertained which needs more elaborate study.

a. Hydroxyurea, which is used to decrease the mortality, complication in sickle cell patients (few case reports already there).

b. Could be due to accumulation of multiple genetic abnormalities over the long years, due to a high degree of proliferative activity of BM cells (sickle cell patient lives longer with the help of hydroxyurea, leading to more accumulation of different mutation and more manifestation of malignancies).

\section{AUTHOR CONTRIBUTION}

First Author: Designed the study and draft the manuscript

Second Author: As a clinician, enrolled the patients and correct the drafted manuscript.

Third Author: Collect the literature and helped to draft the manuscript. He has done the statistical part also.

\section{CONFLICTS OF INTERESTS}

$\mathrm{Nil}$

\section{REFERENCES}

1. Steensma DP, Gibbons RJ, Higgs DR. Acquired alpha-thalassemia in association with myelodysplastic syndrome and other hematologic malignancies. Blood 2005;105:443-52.

2. Paydas S. Sickle cell anemia and hematological neoplasias. Leuk Lymphoma 2002;43:1431-4.

3. Goldin AG, Kelty KC, Beard MF. Sickle cell anemia terminating in acute myeloblastic leukemia. Ann Intern Med 1953;39:920-8.

4. Anderson IS, Yeung KY, Hillman D, Lessin LS. Multiple myeloma in a patient with sickle cell anemia. Interacting effects on blood viscosity. Am J Med 1975;59:568-74.

5. Nowell PC, Jensen J, Gardner F. Two complex translocations in chronic granulocytic leukemia involving chromosomes 22,9 , and a third chromosome. Humangenetik 1975;30:13-21.

6. Samal GC. Sickle cell anemia with acute myeloid leukemia--(a case report). Indian Pediatr 1979;16:453-4.

7. Salmassi S, Currie ET, Bolf EC, Hernandez M, Kasprisin DO. Management of hodgkin's disease in a patient with sickle cell anemia. Cancer 1981;48:252-4.
8. Johnson FL, Look AT, Gockerman J, Ruggiero MR, Dalla-Pozza L, Billings FT $3^{\text {rd }}$, et al. Bone-marrow transplantation in a patient with sickle-cell anemia. N Engl J Med 1984;311:780-3.

9. Morabito F, Callea V, Brugiatelli M, D'Ascola D, Palazzolo A, Neri A, et al. Non-hodgkin's lymphoma associated with sickle cell disease: A case report. Tumori 1987;73:523-4.

10. Labi M, Haponik EF, Welsh RA, Summer WR. Alveolar cell carcinoma complicating sickle cell anemia: A chance occurrence? Am J Hematol 1989;32:222-5.

11. Tawfik OW, Moral LA, Richardson WP, Lee KR. Multicentric bilateral renal cell carcinomas and a vascular leiomyoma in a child. Pediatr Pathol 1993;13:289-98.

12. Shokunbi WA, Campbell OB, Ogunbiyi JO. Malignant haemangioendothelioma of bone in a HbSC disease patient-a case report. Afr J Med Med Sci 1996;25:293-6.

13. Stricker RB, Linker CA, Crowley TJ, Embury SH. Hematologic malignancy in sickle cell disease: Report of four cases and review of the literature. Am J Hematol 1986;21:223-30.

14. Platt OS, Brambilla DJ, Rosse WF, Milner PF, Castro O, Steinberg MH, et al. Mortality in sickle cell disease. Life expectancy and risk factors for early death. N Engl J Med 1994;330:1639-44.

15. Baron BW, Mick R, Baron JM. Hematuria in sickle cell anemia-not always benign: Evidence for excess frequency of sickle cell anemia in African Americans with renal cell carcinoma. Acta Haematol 1994;92:119-22.

16. Dawkins FW, Kim KS, Squires RS, Chisholm R, Kark JA, Perlin E, et al. Cancer incidence rate and mortality rate in sickle cell disease patients at howard university hospital: 1986-1995. Am J Hematol 1997;55:188-92

17. Gurney JG, Severson RK, Davis S, Robison LL. Incidence of cancer in children in the united states. Sex-, race-, and 1-year age-specific rates by histologic type. Cancer 1995;75:2186-95.

18. Miller BA, Ries LA, Hankey BF, Clegg L, Edwards BK. SEER cancer statistics review: 1973-90. Bethesda, MD: National Cancer Institute, NIH Pub; 1993. p. 93-2789.

19. American Cancer Society. Cancer Facts and Figures for Minority Americans. Atlanta: American Cancer Society, Information pamphlet; 1991.

20. Schultz WH, Ware RE. Malignancy in patients with sickle cell disease. Am J Hematol 2003;74:249-53.

21. Steinberg MH, McCarthy WF, Castro O, Ballas SK, Armstrong FD, Smith $\mathrm{W}$, et al. The risks and benefits of long-term use of hydroxyurea in sickle cell anemia: A 17.5 year follow-up. Am J Hematol 2010;85:403-8.

22. Dawkins FW, Kim KS, Squires RS, Chisholm R, Kark JA, Perlin E, et al. Cancer incidence rate and mortality rate in sickle cell disease patients at Howard University Hospital: 1986-1995. Am J Hematol 1997;55:188-92.

23. Hasan SH, Elongovan S. Conventional and advances diagnostic aids in oral cancer screening-The journey so far. Int J Pharm Pharm Sci 2014; 7:29-33.

24. Mehdinejad M, Khosravi AD, Morvaridi A. Study of prevalence and antimicrobial susceptibility pattern of bacteria isolated from blood cultures. J Biol Sci 2009;9:249-53. 